\title{
Species Diversity of Bumblebees (Hymenoptera: Apidae) from Different Mountain Regions of Kashmir Himalayas
}

\author{
M. S. Saini ${ }^{1}$, R. H. Raina ${ }^{1 *}$, and Z. H. Khan ${ }^{2}$ \\ ${ }^{1}$ Department of Zoology, Punjabi University, Patiala, Punjab, India \\ ${ }^{2}$ Division of Entomology, SKUAST-K Shalimar, Srinagar (J\&K)
}

Received 1 November 2011, accepted in final revised form 7 December 2011

\begin{abstract}
The species diversity of bumblebees was investigated in three provinces Jammu, Kashmir and Ladakh during 2007-2010. Bumblebee queens, workers and males were collected right from the commencement till to the end of flowering stage in all the three mountain regions. In total, 27 species of bumblebees were collected and identified, of which eleven species were common in the two regions, e.g., Kashmir and Ladakh. A list of species assemblages and abundance is provided in each of the mountain ranges. Species diversity of three regions was determined with Shannon-Weiner diversity index and evenness was calculated with indices of Pielou. The obtained results showed species diversity; evenness and species richness were more observable in Kashmir compared with Ladakh and Jammu. The three sample sites within the Kashmir Himalayas indicate significant differences in species diversity; the Kashmir region had higher species diversity and richness than the other regions. Most species of bumblebees were collected in altitudinal ranges of $3000-4000 \mathrm{~m}$. Four species viz. Bombus cornutus, B. parthenius, B. miniatus and B. morawitizianus are recorded for the first time from this region, while $B$. morawitizianus turn out to be the first record to the national list.
\end{abstract}

Key words: Species Diversity; Bumblebees; Kashmir Himalayas.

(c) 2012 JSR Publications. ISSN: 2070-0237 (Print); 2070-0245 (Online). All rights reserved. doi:10.3329/jsr.v4i1.8815

J. Sci. Res. 4 (1), 263-272 (2012)

\section{Introduction}

Bumblebees belong to the genus Bombus Latreille, 1802 of the family Apidae, order Hymenoptera. Bumblebees rank among the most abundant and conspicuous of flower visitors in alpine, temperate and arctic environment of the northern continents. They are called primitively eusocial and are associated with the high lands and play a key role in the functioning of agricultural ecosystems as pollinators of crops, orchards and wild flowers. Almost all species of bumblebees are generalists in their choice of food plants, visiting any remunerative flowers. Their foraging follows a scramble pattern without either recruitment of nest mates to good food sources. These characteristics of bumblebees

\footnotetext{
* Corresponding author: rifat72001@yahoo.co.in
} 
may account for their abundance in cool environments that have a predictable season of adverse conditions, where flowers are often fairly evenly dispersed. The Kashmir Himalayas, a floristically rich region extending from Pirpanjal, has tremendous variation in altitude, latitude, topography, rainfall and climate. This is responsible for great amount of biodiversity of the region, due to the varied geography, location, climate, rainfall and altitude, the vegetation in the area ranges from tropical deciduous forests to temperate and coniferous forests [1]. Temperature of the valley ranges from $-7.8^{\circ}$ (winter) to $36.6^{\circ}$ (summer), with an average Altitude of $1650 \mathrm{~m}$ and experiences a sub Mediterranean climate with annual precipitation of about $105 \mathrm{~cm}$. Because of extreme diverse physiography, the state shows an equally remarkable diversity in climate in its different regions. In the outer plains and outer hill regions of Jammu division the temperature averages around $30.1^{\circ} \mathrm{C}$ with a minimum of $11.5^{\circ} \mathrm{C}$ in winter to a maximum of $40.6^{\circ} \mathrm{C}$ in summer. In the interior of the middle Himalayan region and its adjoining regions it averages $13.3^{\circ} \mathrm{C}$ with mean maximum and minimum temperature of $30^{\circ} \mathrm{C}$ in summer and $-2.1^{\circ} \mathrm{C}$ in winter, respectively.

Bumblebees of Kashmir Himalaya are of particular interest as this narrow corridor of mountain is almost the only major point of contact between the large and divergent bumblebees fauna of Oriental and Palaearctic regions. The fauna of these regions is separated by deserts in central Asia and in China, except for another corridor of contact near Beijing but with relatively few species [2]. Greater Kashmir encompasses almost the entire mountain system that links the high Tibetan (Xizang-Qinghai) plateau in the east with the Hindu Kush, Pamir and Tien Shan mountain ranges to the west and north covering segments of Pir Panjal, Great Himalaya, Zanskar, Ladakh, Karakoram and Hindu Raj ranges which include some of the highest peaks in the world with an altitudinal range of 400-8600m [3].

In Europe distributional patterns of the bumblebees have been linked with climatic factors [4]. High relief of Kashmir provides a broad range of habitats for bumblebees. With respect to climate, Kashmir is summarized into three regions [5]. Sub tropical region of the Jammu foot hills, subjected to summer monsoon; a range beyond Pir Panjal, temperate valley of Kashmir, with most of the rain and snow falling in the months of winter and the rain shadow of the Great Himalaya, an arid alpine region of Zanskar, Ladakh and Karakoram ranges. These three climatic regions differ in their flora influenced by local altitudinal zonation and variation in local exposure [6], contributing towards a broad range of habitats. In comparison with some parts of Himalaya, Kashmir retains relatively large forests yet access to these varied alpine areas is no longer difficult.

There are two hundred and fifty known species of bumblebees present on global basis [7]. The majorities of these species is known as 'true' bumblebees, and have a social worker caste which is more or less sterile. In fauna of British India 23 species of Bumblebees were recorded [8] that included some records from the neighbouring countries; as Myanmar, Bhutan, Nepal, etc. Subsequent workers added 149 species to this list, raising the total species number to 172 , but due to lot of synonymy as put forth by Williams [9] only 47 species stand as valid. Genus Bombus is at present represented by 
47 species from India out of which 26 species are reported from Kashmir alone [10]. Earlier, bumblebee studies from Kashmir Himalaya are based merely on a couple of hundred specimens. The first important collection of bumblebees from Kashmir was made by Col and Nurse in 1901. A complete inventory of this material was never published, although it provided the specimens that have since been described as the types of many nominal taxa [11-15]. Other important collections were carried out by Jacobson in Kashmir and Ladakh during 1912 [16] and by Meinertzhagen in Ladakh during 1925[17]. A preliminary list of the fauna of Kashmir was compiled by Skorikov [18] and discussed the fauna of the entire Himalaya, though his work based on different concepts of the species than what it is present. The only recent revision of some part of the large Himalayan fauna has been conducted by Tkalcu $[15,19]$ and included description of 73 bumblebees from Nepal. Although there are many elements in common between the faunas of Nepal and Kashmir, 16 species that are known from Kashmir are not represented in this collection. Recently he has described several new taxa from the region. The only key that has been intended to cover any part of the Himalayan fauna is that published by Bingham [8].The only commendable job on the bumblebees from Kashmir Himalaya is done by Williams [10], where he reported 29 species of bumblebees including some from Pakistan-administered Kashmir.

With the immense economic importance of these anthophilous insects and their association with entomophilous flowering plants, their species diversity and altitudinal distribution has already been well studied in many countries. Some important works have already been reported by several authors [10-13, 16, 20-22, 29-31]. They not only enlisted these insects, but provided comprehensive account on their associations with the host plants.

The earlier records show that genus Bombus was represented by 26 species from Kashmir Himalaya and 47 species from India as a whole [9, 10]. It is only under the present study that another species viz. B. morawitizianus has been inducted into this list thus raising the total to 48 . Thus the main aim of this study was to evaluate the species richness and diversity of bumblebees in three different mountains regions of Kashmir Himalayas having the altitudional distribution ranging from 1000-5500m amsl.

\section{Material and Methods}

During 2007-10, thirty five major and fifteen minor collection cum survey tours were conducted in various localities situated in the state of Jammu and Kashmir. These include: Anantnag, Baramulla, Bandipora, Budgam, Kupwara, Pulwama, Srinagar, Ganderbal, Shopian, Kulgam, Kargil, Leh, Rajori, Poonch, Udhampur, Doda, Kishtiwar and Ramban, which are located at an elevation ranging from $1000 \mathrm{~m}$ to $5500 \mathrm{~m}$ amsl. These localities were systematically explored, every year twice or thrice (April to July for queens and August to October for workers and males) for the collection of all the three castes of every species. Attention was paid to the areas above $2000 \mathrm{~m}$. Altitude of each site was measured with digital altimeter. Sampling was conducted at sites dominated by the most 
representative vegetation types of the region.

Bumblebees were collected with sweeping hand net made up of nylon cloth and latter killed with ethyl acetate. Some collection was also made with the help of malaise trap. Most of the collections were available from open areas rather than closed ones. The collection was based mainly on random sampling methods, covering different agroecosystem(s). In addition to collection their live photography was done with Olympus camera equipped with different macro lenses. During the study it was found that bumblebee collection with sweeping hand net was found more effective than malaise trap, the latter does not work at high altitude because of very high wind velocity accompanied with intermittent rains.

\subsection{Killing and setting techniques}

The collected insect material was first sorted out in the field and latter brought to the laboratory for further identification and analysis. For the collection of these insects, special transparent killing jars were designed, so as to preserve the colour of the pubescence. As the colour of the pubescence in bumblebees holds great importance in identification of species, so its proper care was taken during the collection period. Keeping in view the delicacy and grace of pubescence, insects killed in the killing jar were continuously shifted to other jar of same size so as to protect the pubescence. After coming to the laboratory, the specimens were pinned with the help of entomological pins of different sizes, keeping in view the size of specimen. After stretching the specimens were appended with data label containing the important information regarding its locality, altitude, date of collection and name of the collector. Later on, stretched specimens were transferred to the storage boxes, poisoned with ethyl acetate soaked cotton and napthalene powder filled in the side grooves of boxes. All the identified specimens have been deposited in the Department of Zoology, Punjabi University, Patiala for future references.

\subsection{Identification}

While dealing with bumblebee taxonomy in general, the following taxonomic characters were found trust worthy, stable and unambiguous viz., colour of the pubescence, ocelloocular area, inter ocellar distance, length of malar space, sculpturing of the labrum, length of antennal segments 3, 4 and 5, mandibular teeth number, 7th tergum \& sternum in females, shape of mesobasitarsus and corbicular area on metabasitarsus and different parts of male genitalia. Two major keys which were helpful and repeatedly consulted in this connection were by Bingham and Williams $[8,10]$.

\subsection{Species diversity index}

Species diversity index of bumblebees was calculated after completing the identification of bumblebees. Species diversity index $(\mathrm{H})$ was calculated with Shannon-wiener function [23] as: 


$$
H=\sum P_{\mathrm{i}}\left(\ln P_{\mathrm{i}}\right)
$$

where $P_{\mathrm{i}}=N_{\mathrm{i}} / N, N_{\mathrm{i}}=$ total number of individuals in a species, $N=$ total number of individuals in all species.

Evenness $(j)$ was calculated to estimate the equitability component of diversity using the formula [24]:

$j=H / \log _{10} S$

Richness was computed by using formula [25]:

ma $=S-1 / \log _{10} N, \quad$ where $S=$ total number of species collected.

\section{Results and Discussion}

During the present investigations 27 species of bumblebees, belonging to 10 subgenera of the genus Bombus were found in the Kashmir Himalaya within an altitudinal range and are shown in Table 1. Subgenus Melanobombus has been found to be represented by maximum number of seven species, followed by Psithyrus with five, Pyrobombus with four, Bombus, Mendacibombus, Subterranobombus and Sibiricobombus with two each while the remaining subgenera such as Alpigenobombus, Megabombus and Orientalibombus have been found to be represented with one species each (Table 2).

Table 1. Total number of bumblebee species recorded from Jammu and Kashmir.

\begin{tabular}{|c|c|c|c|c|c|}
\hline \multicolumn{2}{|c|}{ Sl. No. Name of the species } & \multirow{2}{*}{$\frac{\mathrm{q}}{51}$} & \multirow{2}{*}{$\frac{\mathrm{w}}{159}$} & \multirow{2}{*}{$\frac{\mathrm{m}}{146}$} & \multirow{2}{*}{$\begin{array}{r}\text { Total catch } \\
356\end{array}$} \\
\hline 1. & B. asiaticus Morawitz, 1875 & & & & \\
\hline 2. & B. avinoviellus Skorikov, 1914 & 2 & 48 & 82 & 132 \\
\hline 3. & B. branickii Radoszkowski, 1893 & 1 & 0 & 1 & 2 \\
\hline 4. & B. cornutus Frison, 1933 & 0 & 0 & 2 & 2 \\
\hline 5. & B. ferganicus Radoszkowski, 1893 & 31 & 0 & 78 & 109 \\
\hline 6. & B. haemorrhoidalis Smith, 1852 & 2 & 2 & 21 & 25 \\
\hline 7. & B. himalayanus Skorikov, 1914. & 0 & 2 & 0 & 2 \\
\hline 8. & B. kashmirensis Friese, 1909 & 4 & 12 & 10 & 26 \\
\hline 9. & B. keriensis Morawitz, 1886 & 4 & 43 & 63 & 110 \\
\hline 10. & B. ladakhensis Richards, 1928 & 0 & 12 & 0 & 12 \\
\hline 11. & B. lemniscatus Skorikov, 1912 & 0 & 26 & 10 & 36 \\
\hline 12. & B. lepidus Skorikov, 1912 & 0 & 5 & 3 & 8 \\
\hline 13. & B. lucorum Linnaeus, 1761 & 17 & 67 & 84 & 168 \\
\hline 14. & B. morawitizianus Popov, 1931 & 4 & 0 & 0 & 4 \\
\hline 15. & B. melanurus Lepeleitier, 1836 & 42 & 187 & 203 & 432 \\
\hline
\end{tabular}


Table 1 (contd.)

\begin{tabular}{llrrrr}
\hline 16. & B. miniatus Bingham, 1897 & 0 & 2 & 2 & 4 \\
17. & B. novus Frison, 1933 & 2 & 0 & 0 & 2 \\
18. & B. oberti Morawitz, 1883 & 1 & 0 & 0 & 1 \\
19. & B. parthenius Richards, 1934 & 0 & 2 & 2 & 4 \\
20. & B. personatus Smith, 1879 & 0 & 3 & 0 & 3 \\
21. & B. pyrosoma Morawitz, 1890 & 20 & 0 & 31 & 51 \\
22. & B. rufofasciatus Smith, 1852 & 38 & 155 & 197 & 390 \\
23. & B. semenovianus Skorikov, 1914 & 7 & 32 & 26 & 65 \\
24. & B. simillimus Smith, 1852 & 109 & 200 & 237 & 546 \\
25. & B. subtypicus Skorikov, 1914 & 0 & 40 & 50 & 90 \\
26. & B. trifasciatus Smith, 1852 & 42 & 201 & 138 & 381 \\
27. & B. tunicatus Smith, 1852 & 93 & 251 & 389 & 733 \\
Total & & 470 & 1449 & 1775 & 3694 \\
catch & & & &
\end{tabular}

Table 2. Diversity index, richness and evenness of different subgenera of genus Bombus from Kashmir Himalaya.

\begin{tabular}{lllllll}
\hline $\begin{array}{l}\text { Sl. } \\
\text { No. }\end{array}$ & Subgenus & $\begin{array}{l}\text { Total No. } \\
\text { of ind. in } \\
\text { species }\end{array}$ & $\begin{array}{l}\text { Total No. } \\
\text { of species }\end{array}$ & $\begin{array}{l}\text { Species } \\
\text { diversity } \\
\text { index (H) }\end{array}$ & $\begin{array}{l}\text { Species } \\
\text { richness } \\
\text { (ma) }\end{array}$ & $\begin{array}{l}\text { Species } \\
\text { evenness } \\
\text { (j) }\end{array}$ \\
\hline 1. & Alpigenobombus & 26 & 01 & 0 & 0 & 0 \\
2. & Bombus & 901 & 02 & 0.20892 & 0.338441 & 0.694017 \\
3. & Megabombus & 381 & 01 & 0 & 0 & 0 \\
4. & Melanobombus & 1178 & 07 & 0.56702 & 1.953669 & 0.670952 \\
5. & Mendacibombus & 134 & 02 & 0.03369 & 0.470123 & 0.111916 \\
6. & Orientalibombus & 25 & 01 & 0 & 0 & 0 \\
7. & Psithyrus & 119 & 05 & 0.17392 & 1.927203 & 0.248823 \\
8. & Pyrobombus & 138 & 04 & 0.38958 & 1.401948 & 0.647078 \\
9. & Sibiricobombus & 357 & 02 & 0.00837 & 0.391747 & 0.027805 \\
10. & Subterranobombus & 435 & 02 & 0.01789 & 0.379005 & 0.059429 \\
\hline
\end{tabular}

Species diversity index and richness of bumblebees is found to be highest at altitudinal range of 3000-3999m (1.06115 and 7.492262 respectively) followed by 40004999m (1.02325 and 5.937445); 2000-2999m (0.97794 and 5.006415); 1000-1999m (0.59786 and 1.7996) and lowest diversity index and richness is found at $5000-5500 \mathrm{~m}$ (0.28731 and 0.724527). Evenness of bumblebee species is found to be highest at 5000$5500 \mathrm{~m}$ followed by $1000-1999 \mathrm{~m}$ (Table 3). Species richness is found highest in subgenus Melanobombus (1.927203) followed by Pyrobombus (0.38958); Psithyrus is next 
subgenus in the hierarchy of species richness (1.9272). Evenness is found to be highest in subgenus Bombus (0.694017) while its species richness is lowest (0.338441); three subgenera, Alpigenobombus, Megabombus and Orientalibombus represent only one species each. Lowest species diversity was found in case off subgenus Sibiricobombus (0.00837) (Table 2).

Table 3. Species diversity index, richness and evenness of bumblebee species collected from different altitudes of Kashmir Himalaya.

\begin{tabular}{clllll}
\hline Altitude (amsl) & $\begin{array}{l}\text { Total No. } \\
\text { of species } \\
\text { collected }\end{array}$ & $\begin{array}{l}\text { No. of ind. } \\
\text { in all } \\
\text { species }\end{array}$ & $\begin{array}{l}\text { Species } \\
\text { diversity } \\
\text { index (H) }\end{array}$ & $\begin{array}{l}\text { Species } \\
\text { richness } \\
\text { (ma) }\end{array}$ & $\begin{array}{l}\text { Species } \\
\text { evenness (j) }\end{array}$ \\
\hline $0-999$ & 0 & 0 & 0 & 0 & 0 \\
$1000-1999$ & 05 & 167 & 0.59786 & 1.7996 & 0.855344 \\
$2000-2999$ & 17 & 1570 & 0.97794 & 5.006415 & 0.794783 \\
$3000-3999$ & 25 & 1597 & 1.06115 & 7.492262 & 0.759081 \\
$4000-4999$ & 16 & 336 & 1.02325 & 5.937445 & 0.849791 \\
$5000-5500$ & 02 & 24 & 0.28731 & 0.724527 & 0.954423 \\
\hline
\end{tabular}

The species abundance recorded from Kashmir Himalaya is in the following order: $B$. tunicatus (733); B. simillimus (546); B. melanurus (432); B. rufofasciatus (390); B. trifasciatus (381); B. asiaticus (356); B. lucorum (168); B. avinoviellus (132) ; B. kerie nsis (110); B. ferganicus (109) and B. subtypicus (90). Least abundant species is B. obe rti (1); B. branickii; $B$. cornutus; $B$. himalayanus; $B$. novus are represented by 2 individuals each; $B$. personatus by 3 ; $B$. parthenius; $B$. morawitizianus; $B$. miniatus by 4 ; $B$. lep idus by 8 and $B$. ladakhensis by 12 . The other scarce species recorded include $B$. haemo rrhoidalis (25); B. kashmirensis (26); B. lemniscatus (36); B. semeovianus (65) and $B$. pyrosoma (51). B. morawitizianus (4), which is first record from India was found only once in Gurez valley (Table 1).

Species composition and distributional patterns of Bumblebees varies with altitude. Preference to a specific altitude (1000-5500m), with different mean elevations is observed for each species. Highest diversity is found at 3000-3999m with 25 species and 1597 individuals, followed by 2000m-2999m with 17 species and 1570 individuals; 4000m$4999 \mathrm{~m}$ with 16 species and 336 individuals; $5000-5500 \mathrm{~m}$ is found to inhabit only 2 species (Table 4). These findings are in accordance with the fact that elevation is the main environmental gradient for turnover of species and number of individuals [9, 10]. As far as the species diversity and abundance of bumblebees from three principal zones of Jammu and Kashmir is concerned, valley of Kashmir contributes maximum to both, 
followed by Ladakh and Jammu, respectively (Table 5), this is attributed to the variation in altitude, topography, climate and flora. Bumblebees with different colour patterns tend to be associated with different elevational zones, entirely black coloured pile on the thoracic dorsum is most frequent at $1000-2000 \mathrm{~m}$; at $2000-3000 \mathrm{~m}$ pale coloured pattern of thoracic dorsum predominates; above $3000 \mathrm{~m}$ colour pattern of the thoracic dorsum is strongly banded and in the sub alpine and alpine zones much paler pile is observed. Increasingly, light pile confers an advantage by increasing reflectance of incident solar radiations in habitats with brighter sun light and the less shade at the higher elevation.

Table 4. Distribution of No. of individuals and species by elevation zone within Kashmir Himalaya.

\begin{tabular}{lcccccc}
\hline Sl. No & Altitude, amsl & $1000-1999$ & $2000-2999$ & $3000-3999$ & $4000-4999$ & $5000-5500$ \\
\hline 1. & Individuals & 167 & 1570 & 1597 & 336 & 24 \\
2. & Species & 5 & 17 & 25 & 16 & 2 \\
\hline
\end{tabular}

Table 5. Species diversity index, richness and evenness of bumblebees from Jammu-Kashmir Himalaya.

\begin{tabular}{lcclll}
\hline Region & $\begin{array}{l}\text { No. of } \\
\text { species }\end{array}$ & $\begin{array}{l}\text { No. of } \\
\text { individuals } \\
\text { in all the } \\
\text { species }\end{array}$ & $\begin{array}{l}\text { Species } \\
\text { diversity } \\
\text { index }(\mathrm{H})\end{array}$ & $\begin{array}{l}\text { Species } \\
\text { richness } \\
(\mathrm{ma})\end{array}$ & $\begin{array}{l}\text { Species } \\
\text { evenness } \\
(\mathrm{j})\end{array}$ \\
\hline Jammu & 03 & 69 & 0.47373 & 1.087637 & 0.992892 \\
Kashmir & 19 & 2826 & 0.99286 & 5.215619 & 0.776428 \\
Ladakh & 17 & 799 & 0.91191 & 5.5124 & 0.74112 \\
\hline
\end{tabular}

It is high time to record the diversity, distribution (altitudinal stratification) and population densities of these anthophilous insects. It is rather more important to gather information on association of these insects with the entomophilous flowering plants (particularly the medicinal plants) occurring up to the permanent snow line. It is also important to underline some commercially important bumblebees so that their pollination potential may be exploited to increase the yield of some regional cash crops such as peas, mustard, clover, alfalfa; some vegetables such as brinjal, onion, reddish, tomato, bottle and bitter gourd; some fruit trees including pear, peach, cherry, apricot, almond; variety of citrus plants and numerous medicinal plants. Studies on the pollination biology along with other insect plant associations in the higher reaches of Himalaya can go a long way in protecting and preserving the rarest type of vegetation gene-pool.

It is further suggested that this work may be extended to the remote high altitude areas of entire India, which may be thoroughly screened, so that the actual position of these insects can be brought to light. It is very likely that 18 bumble bee species so far recorded purely from the neighbouring countries (Pakistan, Afghanistan, Bhutan, Nepal, Tibet and 
Myanmar) may be found from Indian faunistic limits. Another major problem with these insects is that in spite of the presence of host plants; the same species may not remain confined to the same place every year. Since, they are very strong fliers so they keep on shifting their colonial sites every year. So while making the complete survey of these insects, Zanskar and Gurez range in Kashmir Himalayan belt and South Indian hills must be taken into consideration with special attention to Nilgiri and Kodakanal hills. More recently, concerns over the dramatic declines of some bumblebee species have led research to focus on trying to understand why some species appear to be both rarer and more susceptible to environmental change than others. Based on studies of forage use by UK bumblebee species, Goulson et al. [26, 27] argue that the rare species tend to be long tongued and have narrower diets, with a very large proportion of the pollen they collect being from Fabaceae. These species are associated with Fabaceae-rich unimproved grasslands, a habitat which has been largely eradicated. In contrast the common species tend to have broad foraging preferences and readily encompass non-native garden plants and mass-flowering crops in their diets [28].

The present study not only demonstrates the importance of different habitats but also provide quantitative evidence in the form of species richness, evenness, and characterization of species diversity and abundance of common bumblebee species portraying their role in pollination. Baseline data generated will serve for the future investigations of bumblebees at habitat level and consequently devising conservation strategies at landscape level.

\section{Acknowledgments}

The authors are grateful to ICAR New Delhi for providing financial assistance. We also acknowledge the Forest, Wild life and Police Departments of Govt. of Jammu and Kashmir for their valuable support during field study. Special thanks are due to Dr. Paul $\mathrm{H}$ Williams, Research Entomologist, BMNH London for confirmation of species identification.

\section{References}

1. W. A. Rodgers, In: Conserving Asia’s natural heritage, ed. J. W. Thorsell (Switzerland, 1985) p. 103.

2. D. V. Panfilov, Acta Geographica Sinica 23, 221 (1957).

3. M. P. Searle, D. J. W. Cooper, and A. J. Rex, Phil. Trans. Royal Soc. London. 326, 117 (1988). http://dx.doi.org/10.1098/rsta.1988.0082

4. A. Pekkarinen, I. Teräs, J. Viramo, and J. Paatela, Notulae Entomologicae. 61, 71 (1981).

5. G. Singh and P. Kachroo Forest flora of Srinagar and plants of neighbourhood (Bishan Singh and Mohinder Pal Singh Dehradun India, 1976).

6. C. Troll, Proc. of the Symp. of the Int. Geo. Union Commission on High-Altitude Geoecology November. 20-22, 1969 at Mainz,Band (1972) p. 20.

7. P. H. Williams, S. A. Cameron, H. M. Hines, B. Cederberg, and P. Rasmont, Apidologie.39, 46 (2008). http://dx.doi.org/10.1051/apido:2007052

8. C. T. Bingham, The Fauna of British India, Including Ceylon and Burma, Hymenoptera, Vol. I, London, UK (1897). 


\section{Species Diversity of Bumblebees}

9. P. H. Williams, Bull. Nat. History Mus. London UK. Entomol. 67, 79 (1998).

10. P. H. Williams, Bull. Nat. History Mus., London, UK. Entomol. 60, 1 (1991).

11. H. Friese, Deutsche Entomologische Zeitschrift. 1909, 673 (1909).

12. H. Friese, Deutsche Entomologische Zeitschrift. 1918, 81 (1918).

13. O. W. Richards, Entomological Monthly Magazine. 64,107 (1928).

14. O. W. Richards, Annals and Magazine of Natural History. 5 (10), 633 (1930). http://dx.doi.org/10.1080/00222933008673177

15. B. Tkalcu, Senckenbergiana Biologica 55, 311(1974).

16. A. S. Skorikov, Russkoe entomologicheskoe Obozrenie 14,119 (1914).

17. O. W. Richards, Annals and Magazine of Natural History 2 (10), 333 (1928). http://dx.doi.org/10.1080/00222932808672888

18. A. S. Skorikov, Doklady Akademii nauk SSSR. 1933, 243 (1933).

19. B. Tkalcu, Acta entomologica bohemoslovaca 86, 39 (1989).

20. T. H. Frison, Record Indian Museum. 37, 339 (1935).

21. A. M. Sabir, A. Suhail, M. A. Rafi, K. Mahmood, and S. Ahmed, Int. Conf. Biological Resources of Pakistan: Problems, success and future perspectives” at University of Arid Agriculture Rawalpindi, Pakistan, (2007) p. 25.

22. A. M. Sabir, A. Suhail, M. A. Rafi, S. Ahmad, M. Saleem, and K. Mahmood, 28th Pakistan Cong. Zool. (Intern.), 2008) p. 74.

23. C. E. Shannon and W. Wiener, The mathematical theory of communication (University of Illinois Press, 1949) p. 177.

24. E. C. Pielou, Ecological diversity (John Willey, New York, 1975).

25. E. C. Pielou, An Introduction to Mathematical Ecology (John Wiley, New York, 1969) p. 326.

26. D. Goulson, M. E Hanley, B. Darvill, J. S. Ellis, and M. E. Knight,. Biological Conservation. 122, 1 (2005). http://dx.doi.org/10.1016/j.biocon.2004.06.017

27. D. Goulson, M. E Hanley, B. Darvill, and J. S. Ellis, J. Insect Conserv. 10, 95 (2006). http://dx.doi.org/10.1007/s10841-006-6286-3

28. D. Goulson, , W. O. H., Hughes, L. C. Derwent, and J. C. Stout, Oecologia. 130, 267 (2002).

29. S. Ahmad, A. M. Sabir, M. A. Rafi, A. Qadir, and M. Asghar, Biol. Diversity Conserv. 2, 1 (2009).

30. A. M. Sabir, A. Suhail, S. Ahmed, and S. Khalid, Int. J. Agric. Biol. 13 (2), 159 (2011).

31. A. M. Sabir, A. Suhail, and M. Arshad, Bumblebees and utilization of food resources in northern Pakistan (Lap Lambert Academic Publishing, Germany, 2011) p. 224. 